\title{
REFERENCES
}

Anderson, C. M. (1956). N.Z. F. Sci. Tech. A, 37, 379.

Arrington, L. R. \& Davis, G. K. (1953). F. Nutr. 51, 295.

Arthur, D., Motzok, I. \& Brannion, H. D. (1958). Poult. Sci. 37, x 8 1.

Dick, A. T. (1954). Aust. F. agric. Res. 5, 5 I 1.

Dick, A. T. (1956). In Symposium on Inorganic Nitrogen Metabolism, p. 445. [W. E. McElroy and W. B. Glass, editors.] Baltimore: Johns Hopkins Press.

Davies, R. E., Reid, B. L., Kurnick, A. A. \& Couch, J. R. (1960). F. Nutr. 7o, 193.

Feaster, J. P. \& Davis, G. K. (1959). Y. Nutr. 67, 3 I9.

Gallagher, C. H., Judah, J. D. \& Rees, K. R. (1956). Proc. roy. Soc. B, 145, 134.

Gray, L. F. \& Daniel, L. J. (1954). F. Nutr. 53, 43 .

Halverson, A. W., Phifer, J. H. \& Monty, K. J. (r960). 7. Nutr. 7r, 95.

Howell, J. McC. \& Davison, A. N. (1959). Biochem. F. 72, 365.

Lewis, D. (1954). Biochem. F. 56, 39 I.

Marston, H. R. (1952). Physiol. Rev. 32, 66.

Miller, R. F., Price, N. O. \& Engel, R. W. (1956). F. Nutr. 6o, 539.

Mills, C. F. (1958). Soil Sci. 85, 100.

Mills, C. F., Monty, K. J., Ichihara, A. \& Pearson, P. B. (1958). F. Nutr. 65, 229.

Sörbo, B. (1958). Biochem. biophys. Acta, 27, 324.

Spaïs, A. G. (1959). Rec. Méd. vét. 135, I61.

Van Reen, R. (1954). Arch. Biochem. Biophys. 53, 77.

Van Reen, R. \& Williams, M. A. (1956). Arch. Biochem. Biophys. 63, 1.

Wainio, W. W., Wende, C. V. \& Shimp, N. F. (1958). Fed. Proc. 17, 330.

Williams, M. A. \& Van Reen, R. (1956). Proc. Soc. exp. Biol., N.Y., 91, 638.

Wilson, L. G. \& Bandurski, R. S. (I958). F. biol. Chem. 233, 975 -

Wynne, K. N. \& McClymont, G. L. (1956). Aust. F. agric. Res. 7, 45.

\section{Selenium in animal health}

\section{By G. A. M. Sharman, North of Scotland College of Agriculture, Veterinary Investigation Service, Aberdeen}

Selenium is a relatively scarce element. According to Goldschmidt (1954), its mean content in the crust of the earth is about 0.09 p.p.m., making it sixty-sixth in the order of abundance. By comparison, the least abundant of the biologically important metals so far established is molybdenum, whose content is 2.3 p.p.m.

Selenium and sulphur are quite closely related crystallochemically and also geochemically. The accepted content of $S$ in the lithosphere is 520 p.p.m., so that the mean S:Se ratio is around 6000:I. In basic plutonic rocks the S:Se ratio is $7000: 1$, and in shales around 4000:1. Se determinations have not been made on many rock types, but $\mathrm{S}$ contents are readily available and Se contents may be inferred from them.

As there are now reports of animal experiments showing that Se is biologically important, interest has become focused on the possibility that areas of soil deficiency exist. In Scotland the lowest soil concentrations may be expected in light-textured soils derived from arenaceous Old Red Sandstone or from Carboniferous sandstone rocks, or from certain but not all granites, with values of the order of 0.05 p.p.m. or less. Deficiency states in animals might be expected in these areas.

Relatively high values are found for sedimentary rocks. In sea-bottom sediments concentrations of $0.1-5$ P.P.m. are reported, the amount increasing with depth of 
sediment. Shales have the highest values amongst the sedimentary rocks and $0.24-$ I.2 p.p.m. are reported in one investigation of European and Japanese shales (Minami, 1935). Animal deficiencies would not be expected here.

Throughout the world there are seleniferous areas with much greater Se concentrations in rocks and soils. The discovery by Beath, Draize \& Gilbert (1934) that certain species of native plant absorb and concentrate Se has been widely used to locate and map the seleniferous soils. These are now known to occur in the western and mid-western states of Canada, of the United States and of Mexico (Trelease \& Beath, I949). Seleniferous areas have also been identified in Colombia (AncizarSordo, I947), Ireland (Walsh, Fleming, O'Connor \& Sweeney, r95 I), Israel (Volcani, Bondi, Lewin \& Newmark, I956) and Australia (Knott, McCray \& Hall, I958).

In North America, soils capable of supporting seleniferous vegetation are found only where the mean annual rainfall is less than $20 \mathrm{in}$, which is insufficient to leach out water-soluble Se compounds. But, in Ireland, where rainfall is relatively high (40-60 in.), Se concentrations of up to 60 p.p.m. are found in low-lying, poorly drained soils of high organic-matter content. These soils are derived from sedimentary rocks, mainly Upper and Middle Carboniferous (Calp) Limestone in association with Upper Avonian Shales and Sandstones.

\section{Selenium-accumulator and selenium-indicator plants}

Plants may be divided into three groups: (I) those which discriminate against Se and absorb little from seleniferous soils, (2) those which absorb Se from seleniferous soils and concentrate it to a limited degree, (3) those which accumulate Se to a considerable extent, including those which are stimulated in growth by Se. These groups can be identified by the following data, derived from Trelease \& Beath (I949).

$\begin{array}{ccc}\text { Group I } & \begin{array}{c}\text { Soil } \\ \text { concentration } \\ \text { (p.p.m.) }\end{array} & \begin{array}{c}\text { Plant } \\ \text { concentration } \\ \text { (p.p.m.) }\end{array} \\ \begin{array}{l}\text { Soya bean } \\ \text { Group 2 }\end{array} & 4 \cdot 0 & 1 \cdot \mathrm{I} \\ \text { Wheat } & 3 \cdot 5 & 40 \\ \text { Barley } & 3 \cdot \mathrm{I} & 22 \\ \text { Group 3* } & & \\ \text { Astragalus pectinatus } & 3 \cdot 5 & 4000 \\ \text { Stanleya pinnata } & 4 \cdot 0 & 1070 \\ \text { *Includes species of genera in the orders Compositae, Leguminosae and Cruciferae. }\end{array}$

Species within genera differ widely in their ability to take up Se. In Wyoming and North Dakota, twenty-four species are known to fall into group 3. Of these the genus Astragalus is represented in British flora by three different species, and the genera Atriplex and Aster are also represented. It is not known if any British species is a potential Se accumulator of the group 3 type. Group 2 contains most of the crop plants but group 3 plants have the dangerous potential of making Se that would be otherwise inaccessible available to plants of group 2 . 


\section{Selenium poisoning in livestock}

Se is highly toxic. It is the only element known to be absorbed by plants in sufficient amounts to cause death from acute poisoning in animals which eat them.

Group 3 plants have a garlic-like smell that makes them offensive to livestock which therefore avoid them under normal grazing conditions. However, in certain circumstances whole flocks of sheep have died in a single night while pastured on ranges infested with seleniferous weeds. Ingestion of group 3 plants, usually in only a single feed, has also caused rapid death from acute Se poisoning in cattle, horses, and pigs. Affected animals stagger for short distances then stand with the head down and the ears drooped. Watery diarrhoea, abdominal pain and bloating are features of the illness, which rapidly develops to coma and death. Post-mortem examination shows haemorrhagic enteritis, acute toxic hepatitis and toxic tubular nephritis. Mucosae of the urinary bladder, the gall-bladder and omasum are inflamed, probably because the Se is eliminated through them.

Chronic Se poisoning is described either as 'blind staggers' or as 'alkali disease'. The two syndromes and the pathology of the two conditions differ markedly. Blind staggers is caused by ingestion of Astragalus bisulcatus and other native range plants in the U.S.A., and alkali disease is caused by the crop plants and grasses when they contain Io-3o p.p.m. Se. It seems likely that the effective Se compounds in the two types of plants are different, and that soluble Se causes the less chronic blind staggers and Se compounds bound to the proteins of the forage plants cause the more chronic alkali disease.

Blind staggers occurs in cattle and sheep after consumption of moderately toxic amounts of seleniferous weeds. Sudden collapse and death due to cardiac insufficiency may occur, without previous clinical signs of illness, after a period of days or even weeks. On the other hand, the animal may start to wander, often in circles, and to blunder into objects in its path and a period of paralysis precedes death. Postmortem examination shows necrotic foci with fibrosis and haemorrhage in the endocardium and myocardium. In addition there are primary mild toxic changes in liver and kidneys.

Alkali disease affects horses, cattle and sheep. The clinical signs are dullness, lack of vitality, emaciation, anaemia, stiffness of the joints, lameness, roughened coat, loss of hair from the mane or tail, and hoof deformities. Brittleness of the wall of the hoof may often be the first sign noted, and in horses it is often detected when preparing the foot for shoeing. In human beings the first signs of chronic poisoning may be brittleness and malformation of the finger nails.

The gross pathology of alkali disease, apart from hair and hoof changes, is primarily atrophy of the myocardium and chronic toxic changes in the liver and kidneys. There are nearly always erosions of the ends of the long bones. The histopathology of alkali disease is more akin to a chronic toxicity than it is in blind staggers. The main lesions are in the heart, liver, kidneys, and gall-bladder.

$19(2) 6$ 


\section{Toxic levels of selenium in the diet and tissues of animals}

Dietary quantities expressed as $\mathrm{mg} / \mathrm{kg}$ live weight can be converted into p.p.m. of dry ration by multiplying by 33 . Thus a minimal lethal dose of $2 \mathrm{mg} / \mathrm{kg}$ represents a dietary concentration of $60-70$ p.p.m. This rough rule for conversion stems from the fact that voluntary intake of food is about $3 \%$ of weight in all species.

The acute toxicity of a single dose of Se has been measured in laboratory animals and to a lesser extent in farm stock. In laboratory animals, the minimal lethal dose ranges from $\mathrm{I} \mathrm{mg} / \mathrm{kg}$ body-weight in rabbits to $3-4 \mathrm{mg} / \mathrm{kg}$ body-weight in rats. Data for farm stock are those of Miller \& Williams (r940a) who place minimal lethal doses at I I $\mathrm{mg} / \mathrm{kg}$ body-weight for cattle, $3 \mathrm{mg} / \mathrm{kg}$ body-weight for horses and $15 \mathrm{mg} / \mathrm{kg}$ body-weight for pigs. Sheep have died after a single dose of $8 \mathrm{mg} / \mathrm{kg}$ body-weight ('Trelease \& Beath, I949).

Tests for subacute toxicity lasting $7-50$ days, have shown dietary concentrations of ro-30 p.p.m. to be lethal to sheep and pigs. In cattle, doses of $2.2 \mathrm{mg} / \mathrm{kg}$ have proved lethal in 6 days, suggesting that the figure for acute toxicity given by Miller \& Williams ( $1940 a$ ) may be too high.

There is a dearth of critical information on the development of toxic signs in long-continued administrations of Se. Wahlstrom \& Olson (I959) showed that ro p.p.m. of dietary Se as selenite lowered the conception rate in gilts, increased the number of stillbirths and reduced the 56 -day weights of piglets. Observations in other species indicate impairment of health at much lower levels. Prolonged feeding of rats at dietary concentrations of 3-4 p.p.m. produced evidence of Se toxicity (Munsell, De Vaney \& Kennedy, I936). Critical evaluation of toxicity in chicks by Reid, Rahman, Creech \& Couch (1958) showed that detectable changes in the red-cell count and in the concentrations of haemoglobin and serum protein and in the albumin: globulin ratio occurred at dietary levels of I p.p.m.

In acute poisoning Se accumulates in all tissues except the hide and hair; the highest concentrations are found in the kidneys, liver, lungs and spleen. Its occurrence in less active tissues appears to be directly related to the time of survival of the animal (Miller \& Williams, 1940b). Retention in the tissues is much greater when naturally occurring organic Se is ingested than when selenite is ingested. Smith, Westfall \& Stohlman (1938) found it to be seven times greater in the liver and twenty-nine times greater in the muscle from the organic source when equal amounts of organic and inorganic Se were given. Organic Se becomes firmly attached to the proteins whereas only a small proportion of inorganic Se combines with protein; the remainder is eliminated (Smith et al. 1938).

After ingestion of sublethal amounts of Se for long periods the element accumulates in the hair and hide. Chemical estimation of hair is therefore a useful guide to the Se status of animals. Olson, Dinkel \& Kamstra (1954) found values of I-4 p.p.m. in the hair of cattle from areas where alkali disease did not occur, whereas cattle on a seleniferous range had values of Io-25 p.p.m., the highest values occurring in autumn. 


\section{Selenium as an 'essential trace element'}

Schwarz ( $195 \mathrm{I} a, b)$ showed that the liver necrosis which develops in rats fed on Torula yeast as the sole source of protein can be prevented by vitamin E ('Factor I') cystine ('Factor 2') or an unknown substance ('Factor 3') present in casein and certain yeasts. Factor 3 was later shown by Scott (1955) to prevent exudative diathesis and the enlarged-hock disorder of chicks, both of which are also prevented by vitamin E. The active principle in Factor 3 was subsequently identified by Patterson, Milstrey \& Stockstad (1957) and by Schwarz \& Foltz (1957) as Se. It is also possible that the active principle of cystine is a trace contamination of $\mathrm{Se}$ (Schwarz, Stesney \& Foltz, I959).

The ability of Factor 3, or Se as an inorganic salt, to prevent 'vitamin E deficiency conditions' in rats and chicks, led to many other experiments comparing the effects of $\alpha$-tocopherol and Se in animals (Table I).

\section{Table I. The effects of $\alpha$-tocopherol and selenium on vitamin $E$ deficiencies}

\begin{tabular}{|c|c|c|c|c|}
\hline Disease & $\begin{array}{l}\text { Animal } \\
\text { species }\end{array}$ & $\begin{array}{l}\text { Preve } \\
\text { Tocopherol }\end{array}$ & $\begin{array}{l}\text { ited by } \\
\text { Factor } 3 \text { or } \mathrm{Se}\end{array}$ & Reference \\
\hline \multirow{7}{*}{$\begin{array}{l}\text { Muscular dystrophy } \\
\text { (white-muscle disease) }\end{array}$} & Rabbit & Yes & No & Draper (1957) \\
\hline & Pig & Yes & No & Grant \& Thafvelin (1958) \\
\hline & $\begin{array}{l}\text { Lamb } \\
\text { (Oregon) }\end{array}$ & No* & Yes & $\begin{array}{l}\text { Muth, Oldfield, Schubert \& } \\
\text { Remment (1958) }\end{array}$ \\
\hline & Lamb & Yes & Yes & Proctor, Hogue \& King (1959) \\
\hline & Calf & Yes & Yes & $\begin{array}{l}\text { Sharman, Blaxter \& Wilson } \\
\text { (1959) }\end{array}$ \\
\hline & Chick & Yes & Partially & Dam \& Søndergaard (I957) \\
\hline & Mouse & Yes & Yes & De Witt \& Schwarz (1958) \\
\hline Toxic liver dystrophy & Pig & Yes & Yes & $\begin{array}{l}\text { Eggert, Patterson, Akers \& } \\
\text { Stokstad (1957) }\end{array}$ \\
\hline Necrotic liver & Rat & Yes & Yes & Schwarz $(1951 a, b)$ \\
\hline degeneration & Mouse & Yes & Yes & De Witt \& Schwarz (1958) \\
\hline Depigmentation of teeth & Rat & Yes & No & Atkerman (1959) \\
\hline Infertility & Rat & Yes & No & $\begin{array}{l}\text { Harris, Ludwig \& Schwarz } \\
(\text { (1958) }\end{array}$ \\
\hline $\begin{array}{l}\text { Encephalomalacia } \\
\text { (crazy chick disease) }\end{array}$ & Chick & Yes & No & $\begin{array}{l}\text { Dam, Nielson, Prange \& Søn- } \\
\text { dergaard (1957) }\end{array}$ \\
\hline Exudative diathesis & Chick & Yes & Yes & $\begin{array}{l}\text { Scott, Bieri, Briggs \& Schwarz } \\
\text { (1957) }\end{array}$ \\
\hline Reduced plasma albumin & Chick & Yes & Yes & Nesheim \& Scott (1958) \\
\hline $\begin{array}{l}\text { In vitro haemolysis of } \\
\text { red blood cells }\end{array}$ & Rat, chick & Yes & No & $\begin{array}{l}\text { Gitler, Sunde \& Baumann } \\
\text { (I958) }\end{array}$ \\
\hline
\end{tabular}

*Muth et al. (1958) found that 0.1 p.p.m. Se in the diet of pregnant ewes prevented white-muscle disease in the lambs whereas 100 i.u. $\alpha$-tocopherol daily, orally or parenterally, did not.

The possibility that Se deficiency might affect farm animals was first investigated by Muth et al. (1958) in Oregon and by Proctor, Hogue \& Warner (1958) in New York State. The New York workers showed that rations containing I.I p.p.m. Se fed to pregnant ewes prevented white-muscle disease in the lambs, whereas rations containing $0.012-0.08$ p.p.m. Se did not. Subsequently Proctor, Hogue \& King (1959) showed that on the New York rations either Se at the I p.p.m. level or 
$\alpha$-tocopherol at the rate of Ioo i.u./day, when given to the pregnant ewes, prevented muscular dystrophy in the lambs. They also prevented the disease by dosing lambs orally with sodium selenate equivalent to $0.5 \mathrm{mg}$ Se/day or with $50 \mathrm{i} . \mathrm{u}, \alpha$-tocopherol every 2 nd day.

In New Zealand, Hartley, Drake \& Grant (1959) reported a reduction in the incidence of congenital white-muscle disease in lambs after oral administration of selenate to pregnant ewes. The delayed type of white-muscle disease was greatly reduced by treatment of lambs with selenate as a single injection of I $\mathrm{mg}$ Se on seven farms and as I $\mathrm{mg}$ orally once weekly on nine farms. Administration of tocopherol at the same intervals was less effective.

In Scotland enzootic muscular dystrophy of calves was shown to occur widely in the Moray Firth area where cattle are wintered indoors from October to May on rations of oat straw and turnips (Blaxter \& Sharman, 1953). Calves are born from January to April and most cases occur when they are first turned out to grass in late April or early May. The disease can be prevented by dosing calves orally with 200 mg $\alpha$-tocopherol once weekly from birth until they are turned out (Sharman, 1954). Later it was shown that $0.25 \mathrm{mg}$ Se as sodium selenate given by mouth daily also prevented the disease (Sharman et al. 1959).

A further development in the use of Se is the discovery by McLean, Thomson \& Claxton (1959) that in areas where muscular dystrophy of lambs occurs and also where it does not there may be increased growth rate in lambs after Se administration. They suggest that 'hogget ill-thrift', the debilitating New Zealand disease described by Clarke \& Filmer (1958), may in part be due to Se deficiency. Poley, Wilson, Moxon \& Taylor (I94I) reported that subtoxic levels of Se produced a positive growth response in chicks. Nesheim \& Scott (1958) showed that Se at the o. I p.p.m. level gave a faster growth rate than $\alpha$-tocopherol alone, but that at 0.04 p.p.m. along with $\alpha$-tocopherol it gave an even greater growth response. One of the signs of Se deficiency in animals is retarded growth rate. Available information shows that a dietary intake of $0^{\circ} \mathrm{I}$ p.p.m. is sufficient to prevent deficiency signs. As toxicity may occur on intakes of $I-4$ p.p.m., the therapeutic index is very narrow.

In deficiency states, radioactivation techniques are required for determination of the extremely small amounts of Se present in soils, food and animal tissues. The great expense of such a procedure is limiting the advance of knowledge in this field.

Little is known about the mode of action of Se in animals. According to Klug, Moxon, Petersen \& Potter (1950), the succinic-dehydrogenase content of rat livers is reduced below normal when a seleniferous ration is given. Bieri (1959) has shown that dietary $\mathrm{Se}$, in the presence of cystine, significantly reduces peroxidation in certain tissues of vitamin E-deficient chicks. It is not a direct action, as $\mathrm{Se}$ and cystine when added in vitro to homogenates do not reduce peroxidation. Much work remains to be done on this subject.

\section{Conclusions}

Selenium has for long been known as a toxic element. Since the discovery in 1957 that it is the active principle in Factor 3 , it has been recognized as an essential trace 
element. Areas of soil and plant deficiency exist: animals in such areas may be adversely affected.

The margin between the toxic level and the dietary level required to prevent deficiency signs in animals is small. Se must not, therefore, be added to mineral mixtures or feeding-stuffs for farm animals.

There is an urgent need for more toxicity tests to be carried out on farm livestock. In the meantime, administration of Se to individual animals is the only safe method of correcting deficiency. In this respect the different retentions by animals of organic and inorganic Se may be of practical importance.

The ability of certain plants to concentrate Se is a barrier against top-dressing of the soil with the element, until information on the behaviour of local flora with regard to Se has been ascertained.

To overcome the expense involved in the use of radioactivation analytical methods, biological tests with farm livestock can be of great assistance in demonstrating areas of Se deficiency.

I am grateful for the assistance of Dr R. L. Mitchell of the Macaulay Institute for Soil Research, Aberdeen, in checking the geological information presented in this paper.

\section{REFERENCES}

Ancizar-Sordo, J. (1947). Soil Sci. 63, 437 .

Atkerman, K. (1959). Brit. F. Nutr. 13, 38 .

Beath, O. A., Draize, J. H. \& Gilbert, C. S. (1934). Bull. Wyo. agric. Exp. Sta. no. zo6, p. I.

Blaxter, K. L. \& Sharman, G. A. M. (I953), Nature, Lond., 172; 1006.

Bieri, J. G. (1959). Nature, Lond., 184, I149.

Clarke, E. A. \& Filmer, D. B. (I958). N.Z. F. agric. Res. I, 249.

Dam, H., Nielson, G. K., Prange, I. \& Søndergaard, E. (1957). Experientia, 13, 493.

Dam, H. \& Sandergaard, E. (1957). Experientia, 13, 494.

De Witt, W. B. \& Schwarz, K. (1958). Experientia, 14, 28.

Draper, H. H. (1957). Nature, Lond., 180, 1419.

Eggert, R. G., Patterson, E., Akers, W. T. \& Stokstad, E. L. R. (1957). F. Anim. Sci. 16, 1037.

Gitler, C., Sunde, M. L. \& Baumann, C. A. (1958). F. Nutr. 65, 397.

Goldschmidt, V. M. (1954). Geochemistry. Oxford: Clarendon Press.

Grant, C. \& Thafvelin, P. (1958). Nord. VetMed. xo, 657.

Harris, P. L., Ludwig, M. I. \& Schwarz, K. (1958). Proc. Soc. exp. Biol., N.Y., 98, 27.

Hartley, W. J., Drake, C. \& Grant, A. B. (1959). N.Z. F. Agric. 99, 259.

Klug, H. L., Moxon, A. L., Petersen, D. F. \& Potter, V. R. (1950). Arch. Biochem. 28, 253.

Knott, S. G., McCray, C. W. R. \& Hall, W. T. K. (1958). QdF. agric. Sci. 15, 43.

McLean, J. W., Thomson, G. G. \& Claxton, J. H. (1959). N.Z. vet. F. 7, 47.

Miller, W. T. \& Williams, K. T. (1940a). F. agric. Res. 60, 163.

Miller, W. T. \& Williams, K. T. (1940b). F. agric. Res. 6r, 353.

Minami, E. (1935). Nachr. Ges. Wiss. Göttingen, N.S. r, 143.

Muth, O. H., Oldfield, J. E., Schubert, J. R. \& Remment, L. F. (1958). Science, 128, 1090.

Munsell, H. E., De Vaney, G. M. \& Kennedy, M. H. (1936). Tech. Bull. U.S. Dep. Agric. no. 543, p. I.

Nesheim, M. C. \& Scott, M. L. (1958). F. Nutr. 65,601.

Olson, O. E., Dinkel, C. A. \& Kamstra, L. D. (1954). S. Dak. Farm E Home Res. 6, 12.

Patterson, E. L., Milstrey, K. \& Stokstad, E. L. R. (1957). Proc. Soc. exp. Biol., N.Y., 95, 617.

Poley, W. E., Wilson, W. O., Moxon, A. L. \& Taylor, J. B. (1941). Poult. Sci. 2o, 17I.

Proctor, J. F., Hogue, D. E. \& King, J. M. (1959). F. Anim. Sci. 18, 1525.

Proctor, J. F., Hogue, D. E. \& Warner, R. G. (1958). F. Anim. Sci. 17, 1183 .

Reid, B. L., Rahman, M. M., Creech, B. G. \& Couch, J. R. (x958). Proc. Soc. exp. Biol., N.Y., 97, 590.

Schwarz, K. (г95ia). Proc. Soc. exp. Biol., N.Y., 77, 818.

Schwarz, K. (1951b). Proc. Soc. exp. Biol., N.Y., 78, 852.

Schwarz, K. \& Foltz, C. M. (1957). F. Amer. chem. Soc, 79, 3292. 
Schwarz, K., Stesney, J. A. \& Foltz, C. M. (1959). Metabolism, 8, 88.

Scott, M. L. (1955). F. Nutr. 56, $3^{87}$.

Scott, M. L., Bieri, J. G., Briggs, G. M. \& Schwarz, K. (1957). Poult. Sci. 36, I 55.

Sharman, G. A. M. (1954). Vet. Rec. 66, 275.

Sharman, G. A. M., Blaxter, K. L. \& Wilson, R. S. (1959). Vet. Rec. 71, 536.

Smith, M. I., Westfall, B. B. \& Stohlman, E. F. (1938). Publ. Hlth Rep., Wash, 53, I 199.

Trelease, S. F. \& Beath, O. A. (1949). Selenium. New York: S. F. Trelease.

Volcani, R., Bondi, A., Lewin, Y. \& Newmark, C. (1956). Refuah vet. 13, 192.

Wahlstrom, R. C. \& Olson, O. E. (1959). F. Anim. Sci. 18, 141.

Walsh, T., Fleming, G. A., O'Connor, R. \& Sweeney, A. (I95 I). Nature, Lond., I68, 88 I.

\section{Adventitious metals in processed foods}

\section{By E. M. CHATt, British Food Manufacturing Industries Research Association, Randalls Road, Leatherhead, Surrey}

Primitive man consumed all his food in the raw state. If we could believe Charles Lamb (1823) an enthusiasm for roast flesh arose through the attractive aroma evolved when a pigsty caught fire. As one age succeeded another, roasting on an open hearth was superseded by cooking in utensils.

As soon as man secured a measure of domination over other animals, he began to exercise his ingenuity to obtain increased production of the foods yielded by them. The next advance was to preserve the surplus food for future use. To this end, processing in one form or another was devised, such as drying, salting, the addition of spices and preservation by means of fermented liquors. It is exactly 150 years since the first experiments on preserving food over long periods were made by Appert (1810).

Simultaneously with the progressive developments with flesh foods, attention has been directed to the promotion of increased yields of crops. Unfortunately, the concentration of plants of one kind in a relatively small space greatly increases the hazards of their destruction by pests, therefore chemical control is imperative to combat the depredations by insects and fungi. Some of the sprays used are compounds of toxic metals, and minute amounts of these are liable to persist and be carried into the finished products.

This survey is concerned with the presence of adventitious metals in processed foods, but no sharp line of demarcation can be drawn between raw materials and manufactured foods because most of the commodities delivered at the food factory have undergone some form of primary processing, for example curing of cocoa, drying of fruit or pulping of it in preparation for jam-making, extraction of gelatin from hides and rendering or refining of fats. On the other hand, commodities such as highly refined sugar, wheat flour, cornflour, confectioners' glucose, treacle, condensed milk, butter, dried eggs and wine and spirits are among the raw materials used in the food industry.

Adventitious metals may be present in many of the raw materials as received and further contamination is liable to occur in the factory. With canned foods, absorption of tin and iron by the contents progresses after the goods have left the factory. 